Linguistics and Literature Journal
Vol. 1, No. 2, 40-45
E-ISSN: 2723-7273

\title{
THE REPRESENTATION OF IRAN AND UNITED STATES IN DONALD TRUMP'S SPEECH: A CRITICAL DISCOURSE ANALYSIS
}

\author{
Paulina Sefrinta Indah Ivana ${ }^{1}$, Suprayogi Suprayogi ${ }^{2}$ \\ Universitas Teknokrat Indonesia ${ }^{1,2}$ \\ paulinaindahivana@gmail.com ${ }^{1}$, suprayogi@ teknokrat.ac.id ${ }^{2}$
}

\begin{abstract}
Speech plays an important role to shape public perception as it is delivered by an influential figure and reflects the points of view of its speaker. This study discusses a speech delivered by the United States President, Donald Trump, which discusses the conflict between Iran and America. This study was conducted to reveal the representation of Iran and the United States in one of Donald Trump's speeches. The method used in this study is the descriptive qualitative method. The data in this study are in the form of words, phrases, clauses, and sentences that indicate the position of Iran and the United States taken from the speech transcript from the official website of The White House. Data were analyzed under the framework of Van Djik's Socio-Cognitive Approach, consisting of text, socio-cognitive, and social context. Based on the analysis, it can be concluded that Iran is described as a country that has nuclear ambitions and acts of terror that support the existence of terrorists. On the other hand, America is described as having an invincible power. At a socio-cognitive level, Donald Trump is considered a knowledgeable figure on his country's political condition because he knows the weaknesses of Iran and can properly take every decision. Donald Trump also has the authority as a President to make The United States and the countries of the world can work together for peace world. Thus, from the level of social context, countries in the world support the actions taken by America and are very alarming about what Iran has done. The finding suggests that the Socio-cognitive approach is practical to analyze the representation of an issue in speech reflected in linguistics expression and the discourse structure.
\end{abstract}

Keywords: critical discourse analysis, Iran and United States conflict, representation, socio-cognitive approach

\section{INTRODUCTION}

The world is surprised by the possibility of the outbreak of World War III due to strained relations between Iran and the United States. It is feared by all countries in the world that if World War III happened, it will give an impact on all countries in the world because of the significant role of the United States in the global economy. Relations between Iran and the United States became tense after the US military killed an elite Iranian commander, Qassem Soleimani. The relationship is likely to be the outbreak of World War 3, which is feared by all countries in the world because of the significant role of the United States in the global economy. According to Widiyani (2020), the conflict is escalated after Iran launched an attack on American headquarters after The United States sent a drone strike in the middle of the night in Iran that killed Qassem Soleimani who is known as the person who has connections to terrorism. It is known that the problem of terrorism has become an international problem in today's global community (Pranoto and Yuwono, 2018). Thus, this issue is inseparable from the world leaders' attention.

A few days after that, United States President Donald Trump gave a speech to ask Iran to stop its action. Donald Trump, who is a president, is considered as a social actor in which his actions reflect the representation of social practices depicted from a speech. The term social actor representation in the simple definition refers to how social practice actors are described through a text (Evayani and Rido, 2019). Through his speech, Donald Trump illustrated the significant differences in position between America and Iran, so the question raised in this research is how is the discourse of the representation of Iran and the United States structured in Donald Trump's speech and how both countries are represented in the speech. 
The writers' interest to analyzed the speech because speech is one of the ways to convey a message orally. According to Fairclough (1989), discourse is any use of language, whether it is speaking, an advertisement, or a narration in a textbook. This means that speech becomes one of the important and potential aspects of discourse analysis. Seeing Donald Trump's speech on Iran, the writers try to analyze the existing problems with the CDA approach in which according to Van Dijk (2001) CDA can analyze aspects of discourse, namely ideology, power, and hegemony. This study employs the framework of Critical Discourse Analysis, especially Van Dijk's socio-cognitive approach covering the analysis on text, socio-cognition, and social context. It is because discourse can represent how people use the language in the communication process (Afrianto, 2017).

Critical Discourse Analysis (CDA) is an interdisciplinary approach to the study of discourse that views language as a form of social practice and focuses on ways of social and political dominance produced by texts and speeches (Priatmoko, 2013). Some previous studies related to Critical Discourse Analysis have been conducted. Nejad (2013) analyzed representations of a Presidential speech using Van Dijk's framework. In the same year, Shojaei, Youssefi, and Hoseini (2013) examined the biased interpretation and representations of ideologically conflicting ideas in the news media. Furthermore, Rahimi (2017) analyzed representations of Irania in films using Van Dijk's theory. However, the research of presidential speech, especially the speech of Donald Trump has been limitedly conducted. Thus, this makes the writers interested in researching Donald Trump's speech using Van Dijk's theory, so that the writers can find out the discourse elements in the speech by looking at the detail of each word said by the speaker using detail element that can be related to controlling information displayed by the speaker (Eriyanto, 2011).

\section{METHOD}

In conducting this research, the writers used a descriptive qualitative method. According to Holosko (2010), qualitative research is a type of research that collects and works by interpreting the meaning of data with the use of no-numeric data. This kind of approach focuses on both inductive and deductive processes (Cresswell, 2014 in Suprayogi and Pranoto, 2020) thus it is hoped to shed many interpretations on context and situation (Stake, 2010 in Kuswoyo and Rido, 2020). This method can help to understand the discourse structures of the speech based on the way the text. In this context, qualitative research is used to see the qualitative description of Iran and the United States representation through Critical Discourse Analysis (CDA) especially under the framework of Van Dijk's Sociocognitive Approach. The data used in this study are in the form of word, phrase, clause, and sentence which shows the positioning of Iran and The United States in the speaker's speech.

The data were taken from Donald Trump's speech on a YouTube video, entitled "President Trump's speech after Iran's attack" published by CNN News on January 9th, 2020. In collecting data, the writers downloaded the video, watched the video, and did a transcription of the video manually. After that, to get valid data, the writers checked and compared the validity of the script with the video by watching the video several times. Lastly, the writers selected and classified the sentence structure based on every aspect of Van Dijk's CDA approach into a table showing both the representation of Iran and The United States. The collected data were analyzed by using a three-level analysis of Van Dijk's Socio-Cognitive approach by looking at the characteristics of the text, socio-cognitive, and social context levels. Then, the writers interpret each of the data to see what is the meaning represented in the data through a comparison of the Iranian and United States. After all the data are interpreted, the writers come to a conclusion that is to conclude all the results of the analysis.

\section{FINDINGS AND DISCUSSION}

\subsection{Textual Level Analysis}

In the text analysis, three kinds of the structure become the focus of the analysis. They are macrostructure to see the theme of the text being given, superstructure to see the contents of the speech, and also microstructure to see the smaller structure of the text being analyzed.

\section{Excerpt 1:}

As long as I am president of the United States, Iran will never be allowed to have nuclear weapons. 
From this sentence, we can see that Donald Trump declared his authority as the resident who strictly prohibits the use of nuclear that has been carried out by Iran. In conclusion, the macrostructure of this speech an opinion given by Donald Trump for both The United States and also Iran about how to do and a warning to Iran to stop their bad actions against The US especially about its use of nuclear weapons. In the superstructure, the analysis focuses on how the contents of the speech text are presented, from the perspective of the speaker delivers. In this section, the writers find at least five ideas that become the subject of Iran and the United States cases in Donald Trump's speech, namely 1) The safe condition of American troops, 2) acts of terror and sanctions to be given to terrorists, 3) Iran's nuclear ambitions, 4) hopes for Iran became a peaceful country, 5) and the strength of the United States was unmatched. By knowing these contents, can be concluded that all of them show what is Donald Trump tries to deliver in his speech. The next part of text analysis is a microstructure, wherein this part, three elements can help to classify each of the data to be analyzed. There are syntax elements, semantic elements, and lexical elements.

\subsubsection{Syntax Element.}

To make it easier for readers to understand the overview of the structure analysis process, the writers draw it in the table below and explains each of the points and data found in the tables separated into the part of Iran and part of the United States.

Table 1. Syntax Element

\begin{tabular}{lll}
\hline Syntax Element & \multicolumn{1}{c}{ Iran } & \multicolumn{1}{c}{ US } \\
\hline \multirow{2}{*}{ Sentence Form } & $\begin{array}{l}\text { Iran appears to be standing down, which is } \\
\text { a good thing for all parties concerned. }\end{array}$ & $\begin{array}{l}\text { Our great American forces are prepared } \\
\text { for anything. }\end{array}$ \\
& $\begin{array}{l}\text { Iran will never be allowed to have a nuclear } \\
\text { weapon. }\end{array}$ & $\begin{array}{l}\text { The United States military eliminated the } \\
\text { world's top terrorists Qasem Soleimani as } \\
\text { the head of the Kurds force }\end{array}$ \\
\hline \multirow{3}{*}{ Pronoun } & $\begin{array}{l}\text { We have sent a powerful message to } \\
\text { terrorists if you value your own life you will } \\
\text { not threaten the lives of our people. }\end{array}$ & $\begin{array}{l}\text { We suffered no casualties, all of our } \\
\text { soldiers are safe and only minimal } \\
\text { damas was sustained at our military }\end{array}$ \\
& $\begin{array}{l}\text { Your campaign of terror murder mayhem } \\
\text { will not be tolerated any longer. }\end{array}$ & $\begin{array}{l}\text { We should work together on this and } \\
\text { other shared priorities }\end{array}$ \\
\end{tabular}

In the sentence form, Donald Trump uses a variety of sentence structures which shows how Iran and the United States are represented by how he delivered the speech. In this speech, Trump used both active and passive sentences to describe both countries. For pronoun element, Donald Trump often speaks the words we and you, in which pronoun we are intended as they are American society, and pronoun you is addressed to Iran and terrorists. Pronoun shows someone's position in the discourse. Through pronouns, the speaker can show who they are, and whom they are talking about clearly. Donald Trump uses the word we as American citizens, and our in our soldiers and our military which shows a sense of ownership of all American people who also belong to the military. In contrast, it refers to Iran, he always says you and yours, which can be concluded that Donald Trump strongly recognizes himself as an American and distinguishes it from Iran.

\subsubsection{Semantic Elements}

The following table explains how Iran and the US are represented differently through detail and presupposition.

Table 2. Semantic Elements

\begin{tabular}{lll}
\hline Semantic Element & \multicolumn{1}{c}{ Iran } & \\
\hline & Uran can be a great country peace, and & No Americans were harmed in last \\
stability cannot prevail in the Middle East, & night's attack by the Iranian regime, we \\
Detail & as long as Iran continues to foment violence & suffered no casualties, all of our soldiers \\
& unrest hatred and war the civilized world & are safe and only minimal damage was \\
& must send a clear and unified message to the & sustained at our military bases \\
& Iranian regime &
\end{tabular}




\begin{tabular}{lll}
\hline & The United States will immediately impose & Tens of thousands of ISIS fighters have \\
Presupposition & $\begin{array}{l}\text { additional punishing economic sanctions on } \\
\text { the Iranian regime. These powerful }\end{array}$ & been killed or captured during my \\
& sanctions will remain until Iran changes its & admistration, ISIS is a natural enemy of \\
behavior in recent months.
\end{tabular}

The element of detail is the level of analysis that pays attention to how detailed the speaker conveys what is being discussed because if the text is written in detail and it makes the audience understands just by hearing it at a glance. In addition, that also makes the audience capture the object of conversation accurately. Those sentences are clear that Trump wants to convey to Iran to stop the chaos created, by saying it in detail and clearly. When saying about Iran, he explained in detail that there were no casualties for the Iranian regime's attack that occurred that night. The long, clear expression shows that there is a detailed element used in this section. Thus, it can be concluded that, in delivering the speech, Donald Trump delivered some points in detail for the Americans who survived the attack from Iran, and more sentences were given in detail in explaining things done by Iran, such as when warning Iran to stop its actions, as well as threats that given to Iran.

The last element of semantic is a presupposition. Table 2 shows that both of the sentences entail if Iran does not change its behavior, then sanctions will continue to be given. It is supported by further punishment which reinforces the first statement. In the American table, however, both presuppose that ISIS is a group that must be destroyed. The phrase ISIS is Iran's natural enemy shows that this is a phrase that supports the statement of the previous phrase and this second statement emphasizes that statement. Therefore this sentence proposes that the US kills and captures ISIS fighters, and the ISIS fighter died.

\subsubsection{Lexicon element}

The following table reflects how Iran and the US are represented differently through rhetoric.

Table 3. Lexicon element

\begin{tabular}{|c|c|c|}
\hline Lexicon Element & Iran & US \\
\hline Rhetoric & $\begin{array}{l}\text { - Finally to the people and leaders of Iran, } \\
\text { we want you to have a future and a great } \\
\text { future one that you deserve, one of } \\
\text { prosperity at home and harmony with the } \\
\text { nations of the world. }\end{array}$ & $\begin{array}{l}\text {-The time has come for the United } \\
\text { Kingdom, Germany, France, Russia, and } \\
\text { China to recognize this reality. They must } \\
\text { now break away from the remnants of the } \\
\text { Iran deal or jppoa, and we must all work } \\
\text { together towards making a deal with } \\
\text { Iran that makes the world a safer and } \\
\text { more peaceful place. }\end{array}$ \\
\hline
\end{tabular}

Rhetoric is a technique of speaking or writing that is intended to persuade the audience. Rhetoric is generally used positively so that it can arise emotional responses among the audience. This element is used by the speaker to invite the listener to follow what he wants. The rhetorical element can be found in the phrase we all must work together to make an agreement with Iran that makes the world a safer and more peaceful place. In this phrase, Donald Trump invites other countries to cooperate and break away from the remnants of the Iranian agreement or jppoa aimed at making the world safer and more peaceful. It is also shown by the phrase we want you to have a future and a great future one that you deserve, one of prosperity at home and harmony with the nations of the world, because Donald Trump expressed his desire to make Iran a country that has a bright future. Therefore, it can be concluded that the rhetorical element has been used by Donald Trump in his speech.

\subsection{Socio-Cognitive Level Analysis}

\subsubsection{Knowledge}

Knowledge refers to propositions that explicitly refer to the knowledge conveyed by the author. In his speech, Donald Trump explained in detail the position of Qasem Soleimani. The phrase The world's top terrorist Qasem Soleimani as head of the Kurd Salamone army is personally responsible for some of the worst atrocities he trained shows that as the leader of a country he already knows any dangerous things that can trigger unrest for the country and actions that can be taken to prevent that from happening. His expertise in the military field also made Donald Trump looks very adept at knowing the plans to be made to prevent a return attack. From here, 
Donald Trump looks very observant and careful in considering his decision, so it can be said that Donald Trump is a knowledgeable leader.

\subsubsection{Opinion and Attitude}

In the early part of his speech, Donald Trump gives a greeting good morning to greet the audience, this shows the polite attitude delivered by Donald Trump. Then, Donald Trump also often invites the audience to work together to do things that have been conveyed such as to cooperate and change the world for the better. From there it can be seen that Donald Trump has an open attitude aimed at being able to communicate with each other to the people. Besides that, the way he expressed his opinion about the situation in America which is fine and should be happy Americans should be very grateful and happy, it gives a positive impact on American society and also the countries that support and cooperate with him.

\subsubsection{Ideology}

Through a speech delivered by Donald Trump about the riots between Iran and America, It shows that Donald Trump has power over what he will do to his country. The fact that Donald Trump is the leader of America, makes an ideology to his people. Through his speech, Donald Trump invites the American people not to worry about the incident that befell them, and give warnings and threats to Iran to stop their bad actions that will harm the whole world. He also invites all countries in the world to cooperate to stop the chaos caused by Isis. Thus, those ideologies are formed and will be held as how it should be.

\subsection{Social Context Analysis}

Relations between Iran and America have not been harmonious since the era of the Islamic Revolution of Iran in 1979. Many things have been given by America to Iran such as providing support and cooperation. Since the era of the administration of President George W Bush, President Barack Obama, and the leadership of President Donald Trump, Iran and America are still not in good condition.

Tensions that have re-escalated have made the world wary, which then caused reactions from countries about the conflict between America and Iran. Like the European Union, Bahrain, and Qatar, as well as the reaction from the Pakistani Authority which states that the American attack that killed Qasem Soleimani has the potential to threaten peace and stability in the Middle East region, and called on Iran to stop its actions before it gets out of control. Support came back from Saudi Arabia, which supported the United States' decision, that Sunni Saudi Arabia accused Iran of disturbing the stability of the Middle East region.

Qasem Soleimani is the head of the most elite Al Quds division in the Iranian Revolutionary Guards and is considered the second most powerful person in Iran behind Iran's supreme leader. The Quds Force is a branch of Iranian security forces responsible for operations abroad. Donald Trump mentioned that Qasem Soleimani was the number one terrorist in the world and that the act of killing should have been done long ago. With the conflict, the countries of the world began to condemn the acts of violence carried out by Iran to stop and called for an end to attack after the attack between the two countries.

\section{CONCLUSION}

Based on the data obtained, the authors conclude that the representation of Iran and the United States can be seen from the structured feasibility through text analysis, social cognitive level, and social context level. At the text level, America is described as a country that has power and is invincible. While Iran itself is more represented in sentences detailing actions related to terrorism and nuclear. At a socio-cognitive level, Donald Trump appears to have extensive knowledge, which is demonstrated by his readiness to oppose attacks by Iran. $\mathrm{He}$ is also very observant and careful in considering his decision. The fact that Donald Trump is a President, also forms an ideology for his listeners, that as a leader that has been recognized by all countries in the world, Donald Trump invites the people of America and countries in the world to work together to realize world peace. Finally, the level of social context, in which countries declare that they support what America is doing, and regrettably acts carried out by Iran because if war will occur, it will affect peace and other aspects of the world. This opinion is given because Iran is considered as a country that supports the action of terrorism and will endanger the lives of the world, so many countries oppose the actions taken by Iran. In addition, to find out the discourse of the representation of Iran and the United States in Donald Trump's speech, it is important to analyze the contents of 
the speech through the words conveyed, and analyze the representation of other objects in speeches or other media. Maybe, future researchers who are interested in conducting a broader analysis of Representations of Iran and the United States can focus on relations with other issues, so that the accuracy and knowledge of the two countries will be broader.

\section{REFERENCES}

Afrianto, Afriato. (2017). Grammatical Cohesion In Students' Writing: A Case At Universitas Teknokrat Indonesia. Jurnal Leksema, 2(2), 97-112.

Eriyanto. (2011). Analisis Wacana; Pengantar Analisis Teks Media. Yogyakarta: LKiS Group.

Evayani, Widya. \& Rido, Akhyar. 2019. Representation of Social Actors in Sexual Violence Issue in The New York Times and The Jakarta Post Newspapers: A Critical Discourse Analysis.

Teknosastik: Jurnal Bahasa dan Sastra,17(2), 1-6.

Fairclough, Norman. (1989) Language and Power. London and New York: Longman.

Holosko, Michael J. (2010). An Overview of Qualitative Research Methods. London: SAGE Research Methods.

Kuswoyo, Heri, \& Rido, Akhyar. (2019). Process Types of Transitivity System in Engineering Lecture Introduction: A Pedagogic Discourse. Jurnal Bahasa \& Sastra, 19(2), 85-96.

Nejad, A.M, et al (2013). The Representation of a Presidential Speech: A Critical Discourse Analysis. The Iranian EFL Journal, 9(2), 167-179

Pranoto, B.E. \& Yuwono, U. (2018). Cultural Dynamics in a Globalized World. Proceedings of Asia-Pacific Research in Social Sciences and Humanities. Leader's attitude towards terrorism: A critical discourse analysis of Dr. Mahathir Mohamad's diplomatic letters. Budianta et al (eds), Depok, Indonesia. Page 65-73.

Priatmoko, N.A. and S.P. Cahyono ( 2013). Critical Discourse Analysis Of Susilo Bambang Yudhoyono's Speech. Semarang: Universitas Dian Nuswantoro.

Rahimi, A. And M. Amirian, (2017). A Critical Discourse Analysis of The Representation of Iranians in A Western Movie Not Without My Daughter. Langlit, 3(3), 313-346.

Shojaei A., Youssefi, K., and H.S, Hoseini. (2013). A CDA Approach to the Biased Interpretation and Representation of Ideologically Conflicting Ideas in Western Printed Media. Journal of Language Teaching and Research, 4(4), 858-868.

Suprayogi, S. and Pranoto, B.E. (2020) The Implementation of Virtual Exhibition Project in English for Tourism Class for University Students. Academic Journal Perspective, 8(2), 87-97.

Van Dijk, Teun A. (2001). Critical Discourse Analysis. The Handbook of discourse analysis. Massachusetts: Blackwell Publishers Inc.

Widiyani, Rosmha. 2020. "Tegang Iran Vs Amerika Serikat, Begini Sejarah Hubungan Dua Negara". Detik News, January 11 2020, Jakarta. 